\title{
A PESQUISA CIENTÍFICA NOS DEGRAUS DA BIOÉTICA
}

\section{SCIENTIFIC RESEARCH ON THE STEPS OF BIOETHICS}

\section{LA INVESTIGACIÓN CIENTÍFICA EN LOS DEGRAUS DE LA BIOÉTICA}

\author{
NiLo HeNRIQUe ReIS \\ Professor Titular de Filosofia da Universidade Estadual de Feira de Santana (UEFS), Bahia, Brasil. Atua na graduação \\ e pós-graduação de Filosofia da UEFS. Feira de Santana, Bahia, Brasil. Em estágio de Pós-Doutoramento no Programa \\ de Estudos Pós-Graduados em Filosofia da Pontifícia Universidade Católica de São Paulo (PUC-SP). \\ http://lattes.cnpq.br/9108676959881201 / http://orcid.org/0000-0001-8638-2385 / niloreis@uefs.br
}

\begin{abstract}
RESUMO
0 presente artigo busca refletir sobre as conexões entre a bioética e a dignidade humana, principalmente dentro do âmbito da pesquisa científica. Por esta ótica, entende-se que a dignidade humana deve ser um direito e, igualmente, uma obrigação de uns com os outros, um princípio de responsabilidade que deve ser difundido pedagogicamente entre as ciências, as artes e as profissões. Com efeito, o motivo determinante é o bem da coletividade, devendo este ser garantido pelo ordenamento jurídico, e, acima deste, que se torne o conteúdo moral da ação do indivíduo nas suas relações sociais. É imprescindível conceber uma perspectiva na qual os valores humanos e conhecimentos biológicos podem ser produzidos com engajamento ético. Este argumento concretiza o bojo deste trabalho ao pensar em obrigações correlacionadas e no esquecimento desses compromissos de uns com outros, por parte da comunidade científica.
\end{abstract}

Palavras-chave: Dignidade; Instituições; Obrigação mútua; Temas de Bioética; Vulnerabilidade.

\begin{abstract}
The present article seeks to reflect on the connections between bioethics and human dignity, mainly within the scope of scientific research. In this sense, it is understood that human dignity must be a right and, equally, an obligation among each other, a principle of responsibility that must be disseminated pedagogically between the sciences, the arts and the professions. In fact, the determining motive is the wellbeing of the collectivity, and this must be guaranteed by the legal system, and above that, it must become the moral content of the individual's action in their social relations. It is imperative to devise a perspective in which human values and biological knowledge can be produced with ethical engagement. This argument concretizes the bulk of this work by thinking of correlated obligations and the neglecting of these commitments to one another by the scientific community.
\end{abstract}

Keywords: Dignity; Institutions; Mutual obligation; Bioethics topics; Vulnerability.

\section{RESUMEN}

El presente artículo busca reflexionar sobre las conexiones entre la bioética y la dignidad humana, principalmente dentro del ámbito de la investigación científica. Por esta óptica, se entiende que la dignidad humana debe ser un derecho y, igualmente, una obligación de unos con otros, un principio de responsabilidad que debe ser difundido pedagógicamente entre las ciencias, las artes y las profesiones. En efecto, el motivo determinante es el bien de la colectividad, debiendo éste estar garantizado por el ordenamiento jurídico, y, por encima de éste, que se convierta en el contenido moral de la acción del individuo en sus relaciones sociales. Es imprescindible concebir una perspectiva en la cual los valores humanos y conocimientos biológicos pueden ser producidos con compromiso ético. Este argumento concreta el bulto de este trabajo al pensar en obligaciones correlacionadas y en el olvido de esos compromisos de unos con otros, por parte de la comunidad científica.

Palabras clave: Dignidad; Instituciones; Obligación mutua; Temas de Bioética; Vulnerabilidad. 


\section{SUMÁRIO}

INTRODUÇÃO; 1 A VULNERABILIDADE COMO UMA QUESTÃO ÉTICA; 2 DAS PERSPECTIVAS DA OBRIGAÇÃO MÚTUA, DA RAZÃO E DO CAPITAL; 3 DA EVOLUÇÃO DOS PRINCÍPIOS À CONSCIÊNCIA DA DIGNIDADE; 4 DO JÁ CONQUISTADO VERSUS O A CONQUISTAR; 5 A ESCOLHA É UM PROBLEMA DE CADA EXISTÊNCIA; CONCLUSÃO; REFERÊNCIAS.

\section{INTRODUÇÃO}

A palavra bioética é aqui empregada adotando-se o mesmo sentido proposto inicialmente por Potter, como "um sistema de moralidade baseado no conhecimento biológico e valores humanos, com as espécies humanas aceitando responsabilidades para a sua própria

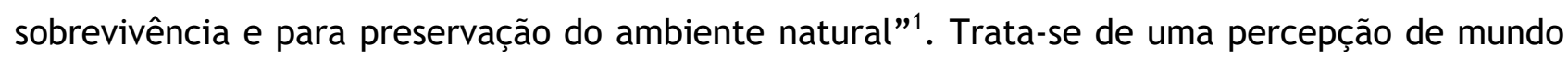
alicerçada no pressuposto de que o conhecimento produzido pelas ciências deve trazer benefícios à sociedade, ao mesmo tempo em que preserva as condições ideais de conservação do meio ambiente para as gerações vindouras.

Por vulnerabilidade entende-se a condição de todo aquele que é exposto à violência devido à sua fragilidade emocional, socioeducativa, sociossanitária, financeira ou cultural, diante das forças empregadas contra seus direitos naturais e sociais, sem a possibilidade de recurso de sua parte contra o quê ou quem o agride. A hipossuficiência, embora seja termo que abarca uma relação específica do direito, serve nestas linhas para completar o conceito de vulnerabilidade aludido nas pesquisas que envolvem seres humanos, nas quais a proeminência da pesquisa desconsidera, no stricto sensu, o respeito pela dignidade humana, ao procurar produzir o saber pelo mero saber.

Emprega-se o termo responsabilidade social em toda e qualquer obra que reúna em sua ação o devido respeito pelo ser humano, ao tempo que elege a dignidade como o seu pressuposto dialético, capaz de aglutinar ações solidárias e, igualmente, plurais, a ponto de conviver com as diferenças culturais, emocionais e, em especial, visões sociais de mundo distintas da sua própria formação.

A emancipação é a meta da cidadania e, da mesma forma, é o que se espera da construção coletiva dos seres humanos, na qual estes sejam capazes de operar os fenômenos sociais numa correlação de direitos e deveres de uns com os outros. Quando se considera o

${ }^{1}$ Potter, V. R. Global bioethics: Building on the leopold legacy. Michigan: Michigan State Press, 1988. p. 153-154. 
sentido do termo emancipação, percebe-se que seu significado vai além da compreensão tomada no discurso jurídico, que o define, em resumo, como liberto do domínio de uma autoridade; porém, devido à sua etimologia, significa também tornar-se livre das ideias e crenças impostas pelas estruturas que organizam o sistema sociopolítico. Tal situação não significa que está imune dos abusos e da influência do próprio sistema, ou que se posicione contrário a estes referenciais. O ser emancipado conhece as condições objetivas do jugo do sistema dominante através das instituições e de suas autoridades; e, conhecendo-as, constitui-se como um ser de direitos ao mesmo tempo em que reconhece na coexistência social, alicerçada em bases democráticas e com diversidade de pensamento, um modo profícuo e dialético de solução de conflitos e superação de injustiças. Todavia, a qualidade da emancipação se expressa no entendimento de que o indivíduo assume que o princípio da dignidade da pessoa humana é um direito inviolável de cada ser humano que reconhece que qualquer ação sociopolítica precisa ser ética, e começa com garantir uma boa vida a todos.

A razão é a sede do conhecimento e, igualmente, o instrumento perceptivo do ser humano. Embora seja a faculdade de raciocinar, é, também, por seu intermédio, o locus onde o indivíduo recebe o conjunto de crenças e padrões partilhados na comunidade em que está inserido desde o nascimento. Na razão se encontram os referenciais de orientação humana, porém, ela se torna uma cativa da educação e das instituições que traçam e modelam a cultura. E, assim sendo, a razão está sempre passiva a ser contaminada, de diversas formas, desde a tenra idade, por um conjunto de crenças e padrões partilhados pela comunidade. Mas, graças às suas potencialidades intelectuais, ela pode, às vezes, se desenvolver de uma forma dialética com a educação, com as instituições e com a própria cultura. Através da razão, que sempre é uma ferramenta, as pessoas estabelecem convivência e relacionamento entre si por meio das relações sociais que exprimem os valores das instituições dominantes.

Por serem referências obrigatórias da existência humana, as instituições, independentemente do modelo político, existem e são substituídas por outras no decurso do tempo. Não obstante, sua função principal é ser um espelho, uma forma reguladora que procura educar o indivíduo para um ideal de ser humano que reflete sua existência nos valores sociais postos nas imagens de sua cultura. 
Deste modo, toda cultura cria uma perspectiva do que seja a realidade e molda as pessoas a seguirem a esta orientação (weltanschauung ${ }^{2}$ ) imposta pela cultura. Essa visão ideológica é mediada pelas crenças consensuais que chegam a não ser sentidas pelos atores sociais. Estes valores ocupam os corpos e as mentes dentro de um determinado tempo e espaço, e, devido ao contexto, ao final, graças à educação, a pessoa será persuadida a reproduzir essas crenças. Em virtude da influência das instituições, as pessoas terão "boas razões" para acreditar que suas crenças são legítimas.

A educação do sujeito ocorre em uma dimensão histórica, na qual o indivíduo é moldado para reproduzir os valores de sua comunidade. Tais valores são passados pelo sistema que une as pessoas por intermédio de regras escritas e não escritas, dando o substrato da própria cultura. 0 aprazimento da cultura é reforçado pelo sentimento de pertencimento a uma comunidade pela ação da razão que procura imprimir um modo mecânico de padrão de comportamento aos interesses da própria comunidade; e é desde a modernidade que se procura passar as crenças como verdades científicas a ponto do indivíduo dirigir suas inclinações pessoais para as metas impostas pela convenção social que, após a contínua reprodução destas ideias pelas relações sociais, ele toma como uma verdade justa para si. Na era das ciências, "os donos da razão" recorrem à influência das ciências para persuadir, de modo mais eficiente, pela educação.

Entretanto, a educação é sentida de maneira particular pelo indivíduo (graças às múltiplas formas que afetam a razão), não somente na orientação delineada pela educação dominante, mas no que se refere a um processo, em si, dialético, que, ao mesmo tempo, procura montar uma compreensão da realidade conforme os interesses dominantes, porém, às vezes, permite descobrir aquilo que estas instituições desejam encobrir. A tensão entre a educação dominante e os seus efeitos indesejados pode ser sentida no momento mais original da ação pedagógica, quando a educação se articula com o sentimento e a razão do indivíduo e lhe dão consciência de si. Essa mediação é incerta, porém, ocasionalmente, sobrevém em um processo lento ao longo do tempo. Como sobredito, a educação pode, às vezes, fornecer uma visão crítica ao indivíduo de sua situação social e da forma como estão estabelecidas as relações com seus semelhantes, a partir dos valores impostos pelas instituições que moldaram a manifestação de seus sentimentos.

\footnotetext{
${ }^{2}$ Este conceito é utilizado segundo a interpretação de Michael Löwy: “um conjunto orgânico, articulado e estruturado de valores, representações, ideias e orientações cognitivas, internamente unificado por uma perspectiva determinada, por um certo ponto de vista socialmente condicionado". LÖWY, M. As aventuras de Karl Marx contra o Barão de Münchhausen: marxismo e positivismo na sociologia do conhecimento. São Paulo: Busca Vida, 1987. p. 12.
} 
A educação procura fazer uma transferência dos valores dominantes sem resistências e com a contribuição efetiva da razão que exerce seu domínio e influência no inconsciente das pessoas, desde a mais tenra idade. A transferência ocorre de modo planejado através da educação que, atingindo o aparato psíquico do indivíduo, faz com que este não perceba que as coisas e valores que busca ou evita socialmente decorreram de uma transferência das instituições. A força da influência da educação na vida do indivíduo não tem limites, e pode ser notada nas linguagens que expressam sua vinculação à comunidade, mas também nas condutas que são tipificadas nos códigos jurídicos, porém, e visto de modo mais eficaz, no sentimento de culpa.

O peso da culpa afetará o comportamento de uma pessoa, causando um mal-estar psíquico que gerará consequências emocionais a ponto de provocar dores físicas. Além das reações emocionais mais comuns, todavia, graças ao uso da razão, torna-se possível escapar das moldagens do sistema cultural e, em seguida, adotar uma orientação inédita sobre sua correlação com as instituições e pessoas. Por meio da razão que busca guiá-lo em padrões prévios, o ser humano desvia-se da vida cotidiana e irrefletida e conhece a estrutura escondida da realidade, aquela que não se oferece diante dos olhos, para que a consciência perceba que só entre os seus semelhantes, e convivendo de modo digno, o homem pode atingir seu potencial máximo.

Continuando os conceitos, há em toda sociedade valores que simbolizam ideais a serem perseguidos por todos. Dentre os muitos, um se tornou a matriz do ideal ético, a base nuclear que fundamenta a existência humana. Este pressuposto é a dignidade. No decorrer do tempo, no qual existiram estruturas condicionantes que moldavam a existência social de modo desigual e injusto, emergiu o valor da dignidade da pessoa humana como ideal ético desejável à comunidade. A sua noção incorpora que a condição prévia e, ao mesmo tempo, o fundamento da boa vida só é possível em meio às outras pessoas, e se houver o respeito pela dignidade humana.

Independentemente das múltiplas percepções culturais, foi constatado na história que a coexistência humana exige um conjunto de princípios ou ideias que, solidamente dispostas por instituições, de um lado a outro, moldam as relações sociais. Em meio às regras de qualquer sistema que formam seu próprio ethos, foi-se paulatinamente reconhecendo, desde a modernidade, que as sociedades, que davam proeminência à coexistência pacífica e à pluralidade de pensamento político para sua organização, adotaram como sustentáculo da boa vida o devido respeito à dignidade como a essência da vida social. Tal compreensão foi depois 
ISSN 1981-3694

(DOI): $10.5902 / 1981369424336$

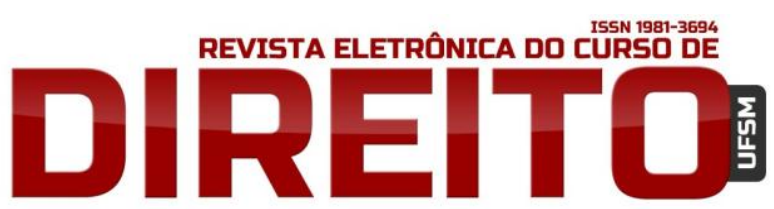

A PESQUISA CIENTÍFICA NOS DEGRAUS DA BIOÉTICA NILO HeNRIQUe REIS

consolidada em declarações universais que se tornaram os imperativos nucleares das constituições democráticas.

Não obstante as conquistas, sem um ativismo enérgico que exigiu um recurso à força ou a persuasão, como vem fazendo a bioética, não haveria transformação social das instituições com o recurso apenas ao incentivo à reflexão dos indivíduos ou nem sequer uma mudança de mentalidade dominante por outra que gerasse efeitos de eliminação ou redução às desigualdades. Ora, quando a distribuição dos bens materiais não é feita de forma equânime, é muito provável que haja desigualdades e conflitos sociais.

A concretude da dignidade humana não se inicia com acesso a exames, remédios e hospitais, mas na eliminação das desigualdades sanitárias e na extensão equânime de usufruto dos recursos naturais e sociais. A ética principalista ${ }^{3}$ promoveu uma tímida mudança que não provocou uma revolução no exercício da atividade científica, principalmente em países em que o sistema jurídico não tomou a devida proteção da dignidade humana como o sentido essencial da vida negando a isonomia sociossanitária a todos. Nas entrelinhas da ética principialista, concentra-se a ideia de que basta evitar riscos aos participantes do protocolo de pesquisa. $\mathrm{E}$ mais: quando estes correm, é forçoso que o pesquisador os contorne sob a ameaça de ser obrigado a fazer uma reparação pecuniária. No que diz respeito a compensar outrem em virtude de um prejuízo, há muito que o contrato social da burguesia regulamentou este instituto, ao menos às parcelas que têm acesso a custear uma defesa comprometida. Além disso, em um sistema no qual as expectativas de justiça são frustradas aos vulneráveis, tal medida em nada parece com uma busca pelo ideal ético.

Por fim, quanto ao princípio de obrigação mútua, entende-se que sua ideia reside na tomada de consciência de si e do outro e, ao mesmo tempo, que esta correlação de alteridade só pode ser instaurada por meio do reconhecimento do outro como ser humano. Além disso, admite claramente que as instituições são veículos de reprodução dos valores dominantes ao passo que considera que as ferramentas existentes no atual modelo de produção da sociedade não são formas efetivas para garantirem a devida dignidade. A par de tais afirmações, o princípio de obrigação mútua declara que, dentro dos limites existentes, é imprescindível proteger o indivíduo. Em seguida ao objetivo essencial do princípio de obrigação mútua, começa a expor que a forma em que a sociedade está organizada não é suficiente para supressão da injustiça, tampouco que os princípios apontados pela ética principalista sejam capazes de serem

\footnotetext{
${ }^{3}$ BEAUCHAMP, T.L.; CHILDRESS, J. F. Princípios de ética biomédica. São Paulo: Loyola, 2002.
} 
os norteadores da pesquisa científica envolvendo seres humanos na medida em que são princípios que não promovem uma intervenção pública na forma de conduzir experimentos.

O princípio de obrigação mútua parte ainda da noção que o problema da alteridade seja a primeira barreira de acesso à devida dignidade e, ao mesmo tempo, sem o enfrentamento consciente deste obstáculo, permite-se que ocorra a primeira violação contra o ser humano: que este seja visto sem sua dignidade. Numa correlação entre humanos, uma vontade não pode se sobrepor a outra sem o consentimento mútuo, e, à medida que se ignora este menor fato, introduz-se a violência. O recurso à violência é uma maneira de se justificar uma ação impositiva. Toda ação deste tipo gera insatisfação, principalmente em uma sociedade em que as rendas são distribuídas de modo tão desigual. Em continuação, a violência se institucionaliza de maneira mais drástica quando não há uma obrigação mútua de zelar pelo bem-estar do outro. Dessa forma, a violência mais acentuada é a que é forjadamente naturalizada, passa despercebida das pessoas e é reproduzida pelo sistema: a desigualdade social.

A sociedade na qual os privilégios de uma diminuta parcela da população são considerados "normais" e, em virtude disso, uma ordenação social é edificada para legitimar esta desigualdade, é uma sociedade que convive com a violência institucionalizada e disfarçada. Para dimensionar a presença desta violência, basta acompanhar a legislação imposta pelas autoridades legislativas e a interpretação dos operadores do judiciário em desfavor dos mais vulneráveis nas disputas forenses. 0 princípio de obrigação mútua reconhece que as ciências ${ }^{4}$ devam continuar sua produção e promoverem os avanços tecnológicos - afinal elas proporcionaram um bem-estar distinto de qualquer quadra de tempo pretérita -, mas também percebe que houve abusos ignominiosos que exigiram a edificação de referenciais éticos para nortear a pesquisa científica. Entretanto, esses referenciais se mostram insuficientes para promover uma mudança significativa na forma de produzir conhecimentos quando envolvem vulneráveis.

Já no que se relaciona à bibliografia, tem-se como o cerne do embasamento a Declaração dos Direitos do Homem e do Cidadão $^{5}$ e a Declaração Universal dos Direitos

\footnotetext{
${ }^{4}$ Partilha-se a ideia defendida de Hume de que "o caminho mais agradável e pacífico na vida é o que segue pelas avenidas da ciência e da instrução, e todo aquele que for capaz de remover algum obstáculo nesse caminho, ou descortinar novas perspectivas, deve, nessa medida, ser considerado um benfeitor da humanidade". HUME, D. Uma investigação sobre o entendimento humano. São Paulo: UNESP, 1999. p. 15-16.

${ }^{5}$ ORGANIZAÇÃO DAS NAÇÕES UNIDAS. Declaração dos Direitos do Homem e do Cidadão. 1789. Disponível em: http://www.direitoshumanos.usp.br/index.php/Documentos-anteriores-\%C3\%A0-cria\%C3\%A7\%C3\%A30-
} 
Humanos $^{6}$, bem como os livros de Potter e Schweitzer arrolados no escrito, que servem como fonte de influência por um ideal ético, e, como a parte mais constitutiva, a Constituição da República Federativa do Brasil. Esta é imprescindível, posto que o que naqueles se apresenta como imperativo, nesta são direitos designativos que expressam as situações jurídicas da organização social. Além disso, o sistema que dá forma institucional à república brasileira elegeu como fundamento do Estado Democrático de Direito o princípio da dignidade da pessoa humana. Deste modo, a ideia nuclear da Carta Magna confere uma qualidade distinta ao princípio, pondoo como a sede e, ao mesmo tempo, a fonte geradora de outros direitos naturais e sociais.

Em resumo, o princípio da dignidade da pessoa humana é o que permite construir uma sociedade ciente de que para os indivíduos serem livres, todos os valores - seja do ponto de vista econômico, de gênero, de cor, idade, perspectiva religiosa ou política - estão obrigados, infraconstitucionalmente, sob o viés desta matriz. De sorte que o princípio de obrigação mútua se conecta ao princípio da dignidade da pessoa com vistas a propor novos caminhos na atividade científica que envolve seres humanos.

No que se refere à proposta, e tendo em vista que o problema ético da pesquisa científica se concentra essencialmente na seletividade de participantes vulneráveis nos protocolos de pesquisa, no decorrer deste escrito são apresentadas perspectivas e respostas imprescindíveis ao desenlace da situação. Sugerem-se posicionamentos administrativos e legais, que cabem ao Estado, assim como as configurações pertinentes aos envolvidos em pesquisas que envolvem seres humanos enquanto cidadãos.

\section{A VULNERABILIDADE COMO UMA QUESTÃO ÉTICA}

Nas disposições institucionais colocadas, ao longo da formação, na mente do pesquisador, de modo que não reflita com cuidado sobre as circunstâncias que estruturam a sociedade, e em que pese uma série de "ismos", nada teve mais preponderância do que a influência do positivismo, que gerou uma atitude ingênua de que o saber deve ser buscado em vista do próprio saber. Nas origens do positivismo pode se encontrar uma influência cartesiana ou um repúdio ao idealismo, todavia, foi a partir desta doutrina que a atividade científica

da-Sociedade-das-Na\%C3\%A7\%C3\%B5es-at\%C3\%A9-1919/declaracao-de-direitos-do-homem-e-do-cidadao1789.html. Acesso em: 11 jan. 2016.

${ }^{6}$ ORGANIZAÇÃO DAS NAÇÕ̂ES UNIDAS. Declaração Universal de Direitos Humanos. 1948. Disponível em: http://www.onu.org.br/img/2014/09/DUDH.pdf. Acesso em: 11 jan. 2016. 
desenvolveu uma matriz de que o saber exige sacrifícios de diversos modos, de sorte que, os vulneráveis que não estavam sob a proteção do direito do Estado foram "usados" em nome do progresso e do desenvolvimento da tecnologia.

Tal pensamento arrima-se na tutela de que a ciência começa com a observação dos fatos e que estes são fenômenos determinados por leis fixas, não cabendo espaço para interesses e valores de ordem emocional. Contudo, o passo mais decisivo para modelar a conduta médica foi dado por Claude Bernard ao introduzir o experimentalismo na prática médica. Cabe a ele a passagem do empirismo passivo ao estudo do fenômeno controlado por uma hipótese orientadora, um tipo de observação crítica e distante das explanações metafísicas. A sua influência foi sentida em diversas áreas. Emile Zola escreve que:

A Medicina empírica e a Medicina experimental, não sendo de forma alguma incompatíveis, devem ser pelo contrário inseparáveis uma da outra. A última palavra do livro (Introdução ao estudo da medicina experimental) é que a Medicina experimental não responde a nenhuma doutrina médica nem a nenhum sistema filosófico. ${ }^{7}$

O pensamento de Bernard exercerá uma influência na mentalidade científica até ser absorvido pelas instituições a ponto de se tornar uma referência na educação médica. Conforme se verá no decorrer deste escrito, quando uma ideia se institucionaliza, ela passa a ser o modelo de orientação a ser reproduzido nas relações sociais. E mais: conforme se observa, as condutas circunscritas ao interior destas instituições tendem a se "flexibilizar" moralmente em virtude dos fins que objetivam alcançar.

Sem assistência jurídica, os danos causados com os tratamentos desumanos foram "flexibilizados" moralmente por não reconhecerem os indivíduos como humanos com direitos inatos até o ponto de serem vistos como “objeto da pesquisa". Com isto, a última noção de humano esvaziou-se e, ao final, com a tradição experimental em ascensão, nem sequer a culpa do ato ignominioso encontrou espaço em sua consciência. Não havendo ilicitude ou má-fé, abriram-se todas as possibilidades para o domínio da busca do saber pelo saber, conforme exemplificado.

Até hoje a questão ética deste meu trabalho não me preocupou, em absoluto. 0 estudo da natureza deixa um homem tão despido de remorsos quanto a própria natureza. Fui em frente, sem pensar em nada a não ser nos problemas com que

\footnotetext{
${ }^{7}$ ZOLA, E. 0 romance experimental e o naturalismo no teatro. São Paulo: Perspectiva, 1984. p. 28.
} 
me defrontava, e o material foi... foi se acumulando naquelas cabanas que você conheceu. ${ }^{8}$

A conduta do Dr. Moreau, personagem de Wells, embora seja uma narrativa ficcional, mostra que os homens são violentos por natureza, e são ainda mais quando a dor do outro não tem voz ou espaço social para manifestação, conforme se nota nos relatos históricos ${ }^{9}$. Esta observação é conhecida, sobretudo pelos pesquisadores, mas desviando um pouco do pretérito para o presente, em uma constatação controversa acerca das pesquisas envolvendo seres humanos, percebe-se uma inclinação seletiva dos pesquisadores em desenvolver seus empreendimentos experimentais nas parcelas mais vulneráveis da população.

Dr. Moreau é uma sátira social, mas a figura que inspirou a literatura foi uma categoria social. Nessa percepção da realidade, a ciência começa e termina sua investigação sem valores, atentando-se exclusivamente na observação do fenômeno e sem interferência das forças externas à própria ciência.

Em “Curso de Filosofia Positiva”, Comte define a prática das ciências: "somente são reais os conhecimentos que repousam sobre fatos observados. Essa máxima fundamental é evidentemente incontestável"10. Depois de séculos de ensino, formou-se uma tradição que acomoda o comportamento ${ }^{11} \mathrm{e}$, ao mesmo tempo, suscita ações condizentes com o que a comunidade instaurou como mecanismo de ação irrefletida. A leitura não impede o indivíduo de reconhecer o outro em sua dignidade, mas independe de sua vontade; uma série de experiências pretéritas são transpostas inconscientemente, as quais são internalizadas como valores que se impõem aos indivíduos.

Como a relação fundamental do sujeito é construída dentro das relações sociais, sua consciência incorpora não só os meios linguísticos para se comunicar com outrem, mas também os valores de sua cultura que, em última instância, estruturam de algum modo sua personalidade com o sistema de crenças elencados por sua sociedade. Graças a uma socialização que começa na infância, os valores são interiorizados pelo indivíduo a ponto de reproduzi-los mecanicamente. De modo que a procura por participantes vulneráveis em protocolos de pesquisa

\footnotetext{
${ }^{8}$ WELLS, H. G. A llha do Dr. Moreau. Rio de Janeiro: Objetiva, 2012. p. 99.

${ }^{9}$ A própria história de como surgiu a ética principialista poderá servir de ilustração do que foi posto aqui, no entanto, a intenção basilar desta nota é mostrar como as pessoas podem desumanizar outras e a si própria devido ao contexto promovido pelas instituições. $E$, neste sentido, recomenda-se a leitura: ZIMBARDO, P. O Efeito Lúcifer: como pessoas boas se tornam más. Rio de Janeiro: Record, 2007.

${ }_{10}^{10}$ COMTE, A. Curso de filosofia positiva. São Paulo: Abril Cultural, 1978. p. 5.

11 De acordo com os autores, sendo o homem o resultado de construto social, foi necessário moldar comportamentos para a convivência em comunidade. BERGER, P. L.; LUCKMANN, T. A construção social da realidade: tratado de sociologia do conhecimento. Petrópolis: Vozes, 1985. p. 74-75.
} 
se torna uma espécie de ação padrão imposta na sua formação. E este caráter repetitivo que se aprende com os mestres se torna o modelo paradigmático da vindoura conduta do ator social.

Todavia, não bastasse uma predileção pelos vulneráveis, quer ainda, em meio a estes, escolher os hipossuficientes. Consoante a interpretação sobredita e o modo de ação interiorizado por uma educação positivista, procura-se aquele que menos pode se opor aos objetivos de sua pesquisa; que, no seu entendimento, visa exclusivamente ao progresso da ciência em nome de um conhecimento cada vez maior. Em verdade, como existe um sistema que cria e enlaça condições objetivas de produção e distribuição de riquezas e poder, o indivíduo assume com a leniência dos valores motivadores da sociedade a ideia de que ele e sua pesquisa são as referências fundamentais, desobrigando-se às proibições de não ver em outrem um ser provido de dignidade. E mais: como a sociedade valoriza a escolha da posse das coisas, o egoísmo natural que desconhece o outro como semelhante encontra as condições para desenvolver-se, permitindo que forme o conceito de que seu trabalho é mais importante do que o ser humano ao lado. Como disse Fromm: “o homem moderno é incapaz de compreender o espírito de uma sociedade que não esteja centrada na propriedade e na avidez"12, e as crenças impostas pelo sistema motivam este comportamento deixando cada vez mais o indivíduo com espaço para manifestação do egoísmo.

Consoante a posição de Berger, o homem é o resultado de um "empreendimento social"13 e, corroborando esta ideia, a compreensão da realidade não é um mero fenômeno que pode ser entendido apenas olhando diretamente o próprio fenômeno, mas envolve o valor das ideias que são postas socialmente. Deste modo, o que se denomina como realidade é, também, um produto cultural que envolve uma projeção afetada pela percepção de quem a vê. Por trás do egoísmo e da pura violência de coisificar as pessoas, existe uma sociedade alicerçada na ideia de que o sucesso do ser humano está na força de seu trabalho e no acúmulo de bens.

Esta é referência central da sociedade: o acúmulo de bens, mas este valor deve ficar encoberto aos olhos ao mesmo tempo em que apresenta um discurso baseado na igualdade de oportunidades para adquiri-los. A partir desta construção da realidade, meios e pessoas se tornam instrumentos, ferramentas em busca da acumulação capitalista. Talvez seja excessiva esta afirmação genérica, contudo, de uma ponta da extração da matéria bruta até o refinamento da mercadoria, todos são envolvidos no mito da máxima eficiência e, de um jeito ou outro, estão submetidos às pressões orçamentárias que impõem restrições. As ciências, como

\footnotetext{
${ }^{12}$ FROMM, E. Ter ou ser? Rio de Janeiro: Zahar, 1980. p. 39.

${ }^{13}$ FROMM, E. Ter ou ser? Rio de Janeiro: Zahar, 1980. p. 39.
} 
se verá adiante, fazem parte constituinte desta lógica de mercado. E não se perceber como ferramenta imprescindível desta realidade montada é, talvez, a evidência de que a falsa consciência esculpiu as condições objetivas da estrutura social através das instituições, dando o valor moral das ações humanas de acordo com o interesse do sistema capitalista.

A título de mera ilustração, se por um lado percebe-se que, por exemplo, uma investigação sobre o carcinoma epidermoide da vagina pode ter como participantes adolescentes do subúrbio marginalizado e seria bastante aceita pela comunidade acadêmica, já por outro lado, nota-se que um estudo que se proponha a entender as representações simbólicas do trauma ocasionado por estupro de menores por padrasto membro das classes abastadas não atrairia a consideração dos pesquisadores. Este último, decerto, caso ocorra, exigiria uma ponderação meticulosa dos riscos. Em verdade, dificilmente um estudo desta natureza seria levado adiante em solo pátrio, embora tal pesquisa possua relevância social e poderia contar com um método que garantisse a viabilidade técnica do empreendimento. No entanto, parece que os pesquisadores não querem se imiscuir em uma classe tão sensível a ponto de evitar investigar as consequências emocionais de danosa prática.

É quase uma constatação irrefutável que não haverá protocolos de pesquisas nesta temática. Tal conduta proporciona uma clareza sobre as investigações que envolvem seres humanos e a escolha dos participantes do protocolo: eles são pessoas que possuem rendas significativas e sabem manejar todo o aparato judicial na defesa de seus direitos, o que gera, no mínimo, um desconforto por parte do pesquisador. Diante do exposto, a escolha da pesquisa parece mostrar que ela não gira em torno da complexa questão do tema, mas dos "riscos" que estes participantes representam aos pesquisadores.

Assim, parece claro que somente com a tomada de consciência do pesquisador de que na seletividade do participante do protocolo de pesquisa começa a questão da alteridade, na qual cada um é para outrem outro um, não seja suficiente para uma transformação radical que mude o comportamento dos atores sociais. E se tal problema existencial não é enfrentado, não se verá o outro como deve ser visto: um ser humano que possui direitos inatos e invioláveis. Afinal de contas, coisificar outrem é a maneira de não se colocar diante de um diálogo verdadeiro $^{14}$. A observação simples do outro como um e vice-versa passa a ser conflituosa e só pode ser vencida de modo profícuo quando se instala a dignidade como medida de correlação entre ambos. Cabe a ela a supressão do egoísmo que cria barreiras. Conquanto, esta dignidade

\footnotetext{
${ }^{14}$ Segundo o filósofo e teólogo, para que haja um diálogo autêntico entre as partes, torna-se necessária a existência de uma reciprocidade entre as pessoas. BUBER, M. Eu e tu. São Paulo: Centauro, 2001.
} 
ainda é mais um imperativo do que um direito do cidadão e um dever do Estado, quando se trata dos vulneráveis, eis que se coloca o princípio de obrigação mútua.

\section{DAS PERSPECTIVAS DA OBRIGAÇÃO MÚTUA, DA RAZÃO E DO CAPITAL}

De acordo com um dito sentencioso, "o direito de um termina quando começa o do outro", mas o princípio de obrigação mútua renega este axioma ao postular a ideia de que os direitos fundamentais das pessoas coexistem simultaneamente. A partir dessa percepção, procura ter uma aplicabilidade fundadora e, de maneira simultânea, ser a fonte subsidiária que une o conteúdo moral e o estatuto jurídico da ação humana no compromisso social proposto pela expressão “cidadania”.

O princípio de obrigação mútua parte do viés que toda pessoa deseja ser reconhecida como ser humano, sendo capaz de gozar os direitos inerentes instituídos pela sociedade em que vive e, de natureza igual, sabe que é imprescindível garantir, como um dever de sua parte, o tratamento igualitário a seus semelhantes. Esse princípio tem por objetivo organizar a existência coletiva, mediante normas e práticas sociais, parte indispensável à ordenação humana que, ao mesmo tempo, sobrepuje a instalação da desordem social.

Ora, é publicamente perceptível que a vida social produz benefícios às pessoas. Esta vida social não implica em perda da liberdade. Ao contrário, reivindica a responsabilidade de cada um de modo incisivo, pois a escolha individual recai no problema da moralidade, que pressupõe o bem de todos e, por conseguinte, exige que a vontade seja boa, que só pode ser boa se, e somente se, é reta e produz justiça. A responsabilidade começa pela ação de escolher participantes vulneráveis quando os fins da pesquisa resultem na promoção da igualdade e do bem-estar do que no interesse da vontade do pesquisador.

Platão, em A República ${ }^{15}$, procura mostrar que só a justiça é uma excelência que produz felicidade. Desse modo, o homem justo procura levar uma vida adequada para as realizações de suas virtudes. Aristóteles, que busca o ideal de felicidade, em Ética a Nicômaco ${ }^{16}$, segue a linha de que seres racionais a desejam por ser um dos bens, mas ele não especifica o que seja este bem. Não obstante, em outra obra, Política, afirma que "a cidade é uma criação natural, e que o homem é por natureza um animal social, e um homem que por natureza, e não por mero

\footnotetext{
${ }^{15}$ PLATÃO. A República. São Paulo: Fundação Calouste Gulbenkian, 2001.

${ }^{16}$ ARISTÓTELES. Ética a Nicômaco. São Paulo: Atlas, 2009.
} 
acidente, não fizesse parte de cidade alguma seria desprezível ou estaria acima da humanidade" ${ }^{17}$. Com esta sentença, Aristóteles deixa nas entrelinhas a compreensão de que o homem é um ser que produz a si mesmo, entre outros homens, e, portanto, dada esta natureza da espécie humana, essa criatura é essencialmente social.

Tanto na primeira quanto na segunda obra, Aristóteles completa a sua interpretação com a ideia de que o fim do homem é desfrutar de uma felicidade e que, entretanto, esta é consequência de sua atividade associada à virtude. A política passa a ser a ciência da felicidade, pois só vivendo em comunidade pode desenvolver suas potencialidades. Contudo, para tanto é indispensável que a cidade esteja convenientemente organizada. Para Aristóteles, esta ordem passa pela maneira que torna possível viver bem e, em seguida, pela instalação de uma forma de governo capaz de garanti-la. Ora, a sociedade, então, tem em vista um bem e, dentre os muitos que existem, a felicidade é o principal. Portanto, torna-se conveniente que seja estabelecido, além da discussão filosófica, um estatuto jurídico que aponte o horizonte moral do que são os bens que devem ser perseguidos socialmente.

Tomando o desejo de felicidade como bem supremo do ser humano, é inevitável estabelecer a correlação de direitos e obrigações de uns com outros, com fim em si mesmo, para garantir àqueles que tenham uma conduta socialmente ética a realização do propósito final de sua existência. Pois bem, o princípio de obrigação mútua, mais do que qualquer prática, afirma que a vida virtuosa só pode ser plenamente boa quando se toma a regra de que toda escolha individual tem que preservar os direitos de outrem. Decorre disto que só o sujeito emancipado é o participante ideal para compor os protocolos de pesquisa. À proporção que compreende o significado da pesquisa e tem consciência de sua cidadania, ele possui uma interpretação da relação produção de conhecimento e respeito à dignidade, sendo capaz de reconhecer quando a inviolabilidade dela foi atingida e, em virtude disso, acionar os meios institucionais, políticos e morais para que os operadores do direito garantam a um só tempo a reparação pela violência no âmbito civil e penal.

Observe que o emancipado, na qualidade de cidadão, sabe que direitos e deveres convivem concomitantemente, portanto, sabe dos cuidados que uns devem com outros, e, sobretudo, consciente da questão da alteridade, sabe discernir o que é uma pesquisa conduzida com responsabilidade social. Além disso, o princípio de obrigação mútua reconhece as dificuldades de implementar essa prática social, mas reconhece também que as desigualdades

\footnotetext{
${ }^{17}$ ARISTÓTELES. A Política. Brasília: UnB, 1985. p. 15.
} 
sociais não isentam as pessoas de escolherem livremente, a qualquer instante. Sabe, ainda, que a ideia de conhecimento em si não se legitima, uma vez que o saber só pode ser produzido com compromisso ético, independente das inclinações da sociedade, entretanto, pretende formar um ethos de que o ser humano possui direitos invioláveis, ainda que esta violação não seja tipificada nos códigos. Consoante à clareza de que a educação pertence à comunidade, entende-se que as convenções apenas regulam a convivência entre seres humanos, porém, o discernimento ético, que transcende o direito, está no enfrentamento da questão da alteridade através do reconhecimento da dignidade que forma a base da moralidade.

Immanuel Kant, em "Fundamentação da metafísica dos costumes"18, buscou o princípio supremo da moralidade, encontrando na boa vontade o único bem que deve ser considerado irrestrito. Trata-se de uma regra aceitável para sujeitos emancipados e com responsabilidade social de uns com outros. E o bom uso da razão permite pensar que esta seja a dimensão ideal da coexistência pacífica.

Todavia, as instituições que organizam a sociedade apresentam crenças e mecanismos que estimulam a desigualdade. E como havia posto Rousseau ${ }^{19}$, estas tendem a acumular-se com o decurso do tempo. De modo que esta razão parece atender aos interesses do sistema dominante e contaminará a boa vontade. Assim, talvez seja melhor, como fez Hume, no "Tratado da natureza humana" ${ }^{20}$, acreditar que a razão não é mais do que uma escrava das paixões. Uma vez que há uma correlação entre as estruturas sociais com o modo de pensar dos indivíduos, o uso da razão procurará promover estímulos que gerem efeitos sobre as ideias. $\mathrm{E}$ como estas são canalizadas e inculcadas nas pessoas por meio das relações sociais moldadas pelas instituições, talvez o caminho mais adequado seja se filiar a Hume, mas por uma perspectiva inusitada, tomando, em parte, o termo "escravo" em seu sentido original, isto é, o de que se vive em absoluta dependência das próprias paixões para propor outras que promovam o fim da desigualdade, o que só pode ocorrer, conforme o princípio de obrigação mútua, com a compreensão das estruturas que formam a perspectiva da realidade, conforme pensava Freud ${ }^{21}$. Caso contrário, vive-se uma existência inteira dominada por pulsões motivadas em crenças interiorizadas pelas relações sociais. De mais a mais sobre a ideia de Kant, não se pode identificar o que se passa no coração das pessoas, portanto, não se saberia se o ato seria fruto

\footnotetext{
${ }^{18}$ KANT, I. Fundamentação da metafísica dos costumes. Lisboa: Edições 70, 2011.

19 ROUSSEAU, J. J. Discurso sobre a origem e os fundamentos da desigualdade entre os homens. Brasília: UnB, 1985.

${ }^{20}$ HUME, D. Tratado da natureza humana. São Paulo: Unesp: Imprensa Oficial, 2001.

${ }^{21}$ FREUD, S. O mal-estar na civilização. São Paulo: Abril Cultural, 1978.
} 
de boa vontade, porém, em uma correlação profícua entre pessoas, as paixões individuais e coletivas devem ser construídas no consenso sob a perspectiva do respeito à dignidade.

A partir da perspectiva aludida, é possível pensar em processos educativos que estimulem determinadas paixões, como o cuidado a outrem, respeito às diferenças, tratamento igualitário, obrigações entre uns e outros, justiça e, em especial, algo que seja protegido pelas normas como o mínimo invulnerável inerente ao humano, pelo qual seja adotado como obrigação mútua: a concretude da dignidade. Todavia, é imprescindível criar artifícios e instituições que promovam estas paixões que causem alegria e eliminem as desigualdades. À vista disso, é indispensável participar de ações que promovam a substituição das instituições atuais por outras comprometidas com o referencial da dignidade. Essas observações sugerem uma mudança social, como a que foi posta em ação pelas diretrizes curriculares nacionais dos cursos das áreas de saúde, que se verá mais adiante.

A ideia de responsabilidade social com o devido respeito à dignidade sugere uma nova maneira de produção científica que se pauta no princípio de obrigação mútua de um cuidar do outro para garantir a inviolabilidade da dignidade. O princípio de obrigação mútua não busca identificar o dano gerado para submetê-lo à reparação (disto ocupam-se os operadores do direito), mas sim edificar meios eticamente mais elevados de se cultivar uma atividade científica com engajamento ético e social ao mesmo tempo em que seja garantida juridicamente, por meio de um Direito mais efetivo, uma análise das condutas e uma punição pelas ofensas à dignidade das pessoas que foram afetadas no nível particular e coletivo. Esse respeito especial gera exigências práticas em uma sociedade complexa, desigual e controversa, que deve ser punida a qualquer violência contra a dignidade pelos mecanismos legais quando cause prejuízo a outrem. Sucede, então, que é preciso institucionalizar a opinião de que o respeito ao princípio de obrigação mútua atende ao interesse comum, ao bem-estar de todos, concedendo-lhe o estatuto moral. E a razão de ser deste juízo resulta da sua busca em promover uma justiça mais concreta. O princípio de obrigação mútua parte da ideia de que uns têm obrigações com outros, e, se a sociedade toma este aprendizado como escolha racional de sua ação, abre-se uma liberdade criativa para vivenciar uma experiência concreta de sensibilidade de cuidar bem do outro, que resultará em um bem para si, que provocará uma crítica aos valores do sistema capitalista.

Todavia, a sociedade contemporânea está estruturada na acumulação de capital. Em virtude disso, a divisão social assume diversas formas para que não seja identificada facilmente e, assim, evite-se o conflito social. Esquece-se, por exemplo, a diversidade de conflitos sociais 
que são provenientes, em grande parte, das desigualdades sociais, e forma-se uma visão de que a busca do saber não deve dimensionar outras questões, posto que o objetivo humano seja conhecer o mundo em que se encontra.

Essa mentalidade foi, paulatinamente, edificada na modernidade sob a crença de que a razão seria o instrumental de libertação do homem, o que promoveu uma passividade diante dos atos aviltantes infligidos a vulneráveis. Não raras vezes, a razão recorreu ao valor utilitário desta medida, uma vez que o mal provocado a poucas pessoas possibilitaria a felicidade de muitos, tornando a reflexão moral refém das forças motivadoras que impulsionam o conhecimento do saber. A razão, assim, passou a legitimar a ideia de que a felicidade de um maior número de pessoas justifica qualquer ação contra um ser humano. Aliás, como a atividade científica era isenta de valor moral, o exercício das ciências deixou de ser visto como abusivo ou feito de forma intencional a prejudicar outrem. Pelo contrário, desde que a razão do esclarecimento despertou de seu sonho medieval através das ciências, os defensores da razão enumeram os benefícios trazidos pelo progresso, com vistas a criar uma sensação de conformismo e, desta forma, uma adesão social às práticas científicas que permitisse sua atividade sem qualquer sanção.

Sob a bandeira do saber, a razão fundamenta que o conhecimento é sempre mais útil do que os meios para se obtê-lo; e com esta perspectiva, as ciências causaram danos morais inaceitáveis. Se "O sono da razão produz monstros" (consoante tela de Francisco Goya), com as ciências o ser humano desadormeceu do estado de sonolência e atingiu o bem-estar material e pode, por esse motivo, dedicar-se ao cultivo das virtudes em suas horas de ócio. A partir desse momento, concebe-se a ideia de que o homem é senhor do seu destino, posto que tudo se torna cognoscível ao intelecto humano. E com o positivismo este sentimento se tornará mais incisivo por considerar a vida apenas pela perspectiva da observação e da experiência. Por acaso do despertar e com o auxílio do positivismo, a figura do protagonista de sua própria história, graças às ciências, o homem se produzirá a si mesmo. Em apertada síntese, a modernidade, como pensa Touraine ${ }^{22}$, proclama a era da razão.

$\mathrm{Na}$ era da razão, as ciências sob a influência das instituições dominantes são incorporadas ao sistema e ao modo de produção e reprodução do capital. Karl Marx ${ }^{23}$, inclusive, acreditava que o aperfeiçoamento tecnológico estava presente na própria sistemática do capitalismo. Sucede que a exploração do ser humano por outro levou a produzir instituições que

${ }^{22}$ TOURAINE, A. Crítica da modernidade. Petrópolis: Vozes, 1997.

${ }^{23}$ MARX, K. O Capital: crítica da economia política. 2. ed. Rio de Janeiro: Civilização Brasileira, 1971. 
garantissem a manutenção dessa exploração, reproduzindo as relações sociais que legitimam o acúmulo do capital. E por sua própria natureza, baseado no que foi posto, percebe-se que o capitalismo, em si, promove as desigualdades sociais. Graças a este modelo econômico, formouse a categoria dos vulneráveis, e dentro dela a esfera dos hipossuficientes. Em uma sociedade movida para conquista do lucro e pela posse contínua dos bens, de modo quase imperceptível, a proposição do sistema econômico de Adam $\mathrm{Smith}^{24}$, com a divisão do trabalho para concentrar a produção, não edificou o bem comum e o bem-estar de todos. Do mesmo modo, a simpatia ${ }^{25}$ humana não foi suficiente para promover um sentimento de ajuda mútua para se organizar uma sociedade mais justa. 0 sistema existente gera desigualdades e por trás de suas justificativas, à luz da verdade encoberta das instituições reinantes, percebe-se que o capitalismo coisifica as pessoas ao mesmo tempo em que tenta encobrir, na era das ciências, que não faz do ser humano mais uma coisa entre tantas outras coisas.

A proeminência científica pode não perceber que as ciências se inscrevem no rol das forças produtivas, obedecendo ao modo material em que a sociedade se estrutura a fim de reproduzir o capital, consoante leitura de Mészáros ${ }^{26}$. As ciências, na firme intenção de compreenderem a realidade, com sua plasticidade criativa, ora reproduzem as necessidades do capital, ora fornecem os ingredientes imprescindíveis ao controle e à produção do capital. Com efeito, as ciências obedecem ao modo material como a sociedade se organiza.

As transformações introduzidas pelo sistema capitalista recorreram a diversos elementos para justificar as suas crenças morais e jurídicas. Estas moldaram um quadro de que a realidade social é dinâmica e flexível aos movimentos de ascensão social pelo trabalho. Não obstante, esta consciência difundida de que o trabalho individual é a mola de ascensão social não expõe a lógica real do sistema com as suas dificuldades para aqueles que estão abaixo da linha de pobreza $^{27}$. A extrema desigualdade gerada pelo sistema precisa mistificar a própria ordenação deste sistema que coisifica as pessoas, seja por meio do recurso da naturalização das

\footnotetext{
${ }^{24} \mathrm{SMITH}, \mathrm{A}$. Inquérito sobre a natureza e as causas da riqueza das nações. Lisboa: Fundação Calouste Gulbenkian, 1980.

${ }^{25}$ De acordo com o economista e filósofo em lide, o egoísmo é o móvel da ação humana. Contudo, haveria nesta mesma natureza princípios que o compelem a querer o bem dos outros. E tomados por estes princípios, seria edificada uma sociedade em que a ajuda mútua aconteceria por um sentimento de solidariedade entre os homens. SMITH, A. Teoria dos sentimentos morais. São Paulo: Martins Fontes, 2015.

${ }^{26}$ MÉSZAROS, I. O poder da ideologia. São Paulo: Boitempo, 2004.

${ }^{27}$ A lógica do sistema é modelada pela elite dominante, com ajuda dos intelectuais, para que as pessoas não percebam que a desigualdade social é resultante da acumulação de capital nas mãos de poucos. SOUZA, J. A tolice da inteligência brasileira: ou como o país se deixa manipular pela elite. São Paulo: LeYa, 2015.
} 
desigualdades, seja pelo uso da força como medida extrordinária. De um modo ou de outro, a crueldade de um sistema não pode ser percebida pelas pessoas. E sob a justificativa da razão despertada de seu sono, uma visão racional e otimista começou a estruturar a compreensão de que só o conhecimento científico era a chave do progresso e da maturidade intelectual do homem. Essa percepção chegou ao apogeu na contemporaneidade, na qual a flexibilidade ética é tomada como ingrediente estético posto ao deleite do cientista:

A ciência é hoje a forma, que informa toda a nossa compreensão e avaliação da realidade, independente (d)e qualquer que seja nossa atitude frente a esse ou àquele resultado científico. Quer atribuamos à ciência valor humano, quer tho neguemos, quer vejamos nela apenas algo indiferente para os valores, a ciência determina sempre o sentido do ser que somos e do ser que não somos. Decide da concepção da verdade em que vivemos, nos movemos e existimos. ${ }^{28}$

\section{DA EVOLUÇÃO DOS PRINCÍPIOS À CONSCIÊNCIA DA DIGNIDADE}

Se no pensamento de Francis Bacon ${ }^{29}$ e René Descartes ${ }^{30}$ se engendrou a teoria que o saber sobre a natureza era a fonte de poder sobre a modulação do real, no mundo moderno ocorreu uma transformação radical, posto que o saber se tornou potência propositiva capaz de alterar a própria funcionalidade da natureza, ou melhor, de agir como bem entendesse sobre esta. Por essa perspectiva, a razão não está mais a serviço da ética, mas ao contrário. A questão básica que se coloca é que os aludidos precursores colocavam a reforma científica sob a moralidade cristã, o que não ocorre mais atualmente, na época científica sob o domínio do sistema capitalista, quando até o ser humano é visto como objeto, coisificado, pensado como força produtiva para reproduzir o capital. Ora, nessa circunstância os valores morais passam a ser secundários ao próprio saber.

Consoante ao que foi posto no início deste texto, inovações filosóficas e jurídicas se entrelaçaram para formar os pressupostos da sociedade capitalista, o que permitiu a difusão da falsa ideia de que as desigualdades são um resultado natural de uma escolha do indivíduo que não se dedica inteiramente a vencer na vida com o esforço de seu trabalho e economia. A razão foi, sem dúvida, o componente líquido que circulou pelos vasos sanguíneos da sociedade, levando os elementos nutritivos necessários para a formação da consciência social, econômica e

${ }^{28}$ LEÃO, E. C. Aprendendo a pensar. Petrópolis: Vozes, 1991. p. 11-12.

29 BACON, F. Novum Organum ou Verdadeiras indicações acerca da interpretação da natureza. São Paulo: Abril Cultural, 1973.

30 DESCARTES, R. Discurso do método. São Paulo: Martins Fontes, 2001. 
A PESQUISA CIENTÍFICA NOS DEGRAUS DA BIOÉTICA NILO HENRIQUE REIS

política de um sistema que fundamenta as desigualdades como legítimas e permite que as ciências determinem o que é a própria realidade, dando uma falsa consciência de que os indivíduos têm direitos e liberdade de escolha de forma igualitária.

Coube à racionalidade científica respaldar a liberdade do sujeito como estandarte imprescindível à sua nova condição de súdito do Esclarecimento (Aufklärung). E foi com o recurso à deusa Razão que os revolucionários franceses redigiram a Declaração dos Direitos do Homem e do Cidadão ${ }^{31}$, um referencial político da modernidade. Paradoxalmente às intenções de dominação do capital, ao colocar a doutrina da liberdade como imprescindível ao mercado, nasceu a ideia de que viver bem resulta em ser livre para se buscar a felicidade, como um fim em si mesmo, possibilitando a concepção de que todos têm direitos inatos. $\mathrm{E}$ este corolário passou a ser a viga do edifício que organiza a vida social. Por meio desse documento, modela-se a nova imagem do homem, ao mesmo tempo em que se reconhece que, individual e coletivamente, existem direitos naturais universais e atemporais que o Estado não pode eximirse de criar as condições para efetivá-los.

A dignidade é um princípio em si que se liga à própria vida e, assim, reflete sobre as instituições do sistema. $O$ advento da proteção a esse princípio foi uma construção histórica, um valor social que depende da consciência que está condicionada à sua reprodução a uma educação que queira destituir crenças dominantes que não entenda a dialética de processo social de reconhecimento da dignidade da pessoa humana. Se o ser emancipado percebeu que o simples fato de ser humano implica em ter direitos naturais e sociais, a educação, por meio das instituições, precisa reforçar a ideia de que existem direitos inatos ao ser humano, ainda que o indivíduo não tenha autonomia do que isso representa em sua consciência e, sobretudo, da existência dos instrumentos legais para manejá-lo. E o resultado desta mudança causará efeitos complexos sobre as pessoas que começarão a entender como funcionam as instituições e, sobretudo, como as crenças são criadas e colocadas nos indivíduos pelas relações sociais. Do mesmo modo ocorrerá com os abusos biomédicos, uma vez que chegou ao conhecimento público que vulneráveis estavam sendo submetidas a atos infames que provocaram um sentimento de aversão às práticas científicas e, igualmente, de solidariedade com as vítimas.

\footnotetext{
${ }^{31}$ ORGANIZAÇÃO DAS NAÇÕES UNIDAS. Declaração dos Direitos do Homem e do Cidadão. 1789. Disponível em: http://www.direitoshumanos.usp.br/index.php/Documentos-anteriores-\%C3\%A0-cria\%C3\%A7\%C3\%A30da-Sociedade-das-Na\%C3\%A7\%C3\%B5es-at\%C3\%A9-1919/declaracao-de-direitos-do-homem-e-do-cidadao1789.html. Acesso em: 11 jan. 2016.
} 
Mas é significativo também notar que foi preciso que o contexto social fosse alterado e que ideias, crenças e instituições fossem transformadas para acolher-se que houve abusos cometidos pelos médicos nazistas. A moderna acepção do Estado Democrático de Direito passou a considerar esses abusos como crimes contra a humanidade. Desde então que a atividade científica, quando viola a dignidade humana, vem sendo criticada por abusos e danos decorrentes. Decerto que ações isoladas merecem o crédito de trazer à tona tal mentalidade, porém, sem que as instituições tomassem tal atitude de considerar um excesso uma violação aos direitos fundamentais, dificilmente os abusos poderiam vir a ser reprovados socialmente. Do que resulta que só por intermédio das instituições, com sua força paradigmática, tais atos possam ser sujeitos à sanção legal. A alusão aos mecanismos institucionais não é acidental, pois quando institucionalizadas as ideias, essas ganham uma dimensão na vida do indivíduo.

Desde que a Organização das Nações Unidas - ONU em 1948 publicou a Declaração Universal dos Direitos Humanos, a ideia de dignidade tem servido como inspiração de horizonte político a ser alcançado pelas pessoas em várias nações. Lê-se, no primeiro Artigo, que “todos os seres humanos nascem livres e iguais em dignidade e direitos. São dotados de razão e consciência e devem agir em relação uns aos outros com espírito de fraternidade" 32 . Em virtude desta ideia, a discussão ética que estava restrita à questão filosófica da alteridade ganhou uma dimensão mais factual, à medida que se percebeu que este ideal ético só será alcançado quando uma obrigação mútua de uns cuidarem dos outros se tornasse o modelo nas relações sociais. Sucede que esta ação não pode ser limitada na tomada de consciência do indivíduo, perpassa por ações coletivas e, acima de tudo, deve estar presente no campo da legalidade jurídica. E desde a publicação da declaração da ONU sobredita que as nações têm adotado esta orientação sociopolítica na sua própria ordenação jurídica.

É imprescindível observar que a prescrição ao respeito à dignidade humana já consta na Constituição do Brasil. No que se refere ao direito, a questão da dignidade está posta. No entanto, é indispensável ainda que as relações sociais reproduzam este valor ao mesmo tempo em que os operadores do direito, que já possuem os instrumentos codificados à mão, tomados pela consciência de que os hipossuficientes merecem proteção especial, debrucem-se sobre a questão da má intenção, negligência e imperícia que a violam. Embora se constatem resoluções

\footnotetext{
32 ORGANIZAÇÃO DAS NAÇÕES UNIDAS. Declaração dos Direitos do Homem e do Cidadão. 1789. Disponível em: http://www.direitoshumanos.usp.br/index.php/Documentos-anteriores-\%C3\%A0-cria\%C3\%A7\%C3\%A30da-Sociedade-das-Na\%C3\%A7\%C3\%B5es-at\%C3\%A9-1919/declaracao-de-direitos-do-homem-e-do-cidadao1789.html. Acesso em: 11 jan. 2016.
} 
e normas que adotam os referenciais bioéticos para a orientação da pesquisa em solo pátrio, olhando bem de perto este cenário, percebe-se que na seletividade dos participantes do protocolo de pesquisa não se pode excluir a ideia de que o problema da alteridade não foi vencido por parte da comunidade científica. De modo que é imperioso que as instituições comprometidas com o verdadeiro bem-estar do ser humano reivindiquem que a lei esteja sempre a favor dos vulneráveis quando sua dignidade for violada.

Este campo do direito vem, no decorrer do tempo, formando uma rede de proteção aos que são considerados cidadãos plenos, por um lado. Por outro lado, a questão da dignidade só pode ser enfrentada substancialmente com a redução das desigualdades. As nações que assinaram a declaração aludida declararam publicamente o desejo de cumprir o princípio da dignidade como regra de coexistência social porque este princípio possui a legitimidade moral que a esfera política requer para fundar o Estado Democrático de Direito. Esta percepção sobre a vida implica um esforço político de torná-la uma perspectiva consciente de que uns têm obrigação com outros na construção da realidade social ideal. Ainda, esta visão ressuscita a crença aristotélica de que os homens são racionais a ponto de organizarem normas e práticas para a vida coletiva em prol de um bem comum.

0 fato material de se colocar na lei o imperativo remete ao sentido de que a prática social tem esse modelo acima das personalidades. Porém, ao introduzir o elemento moral, assume coletivamente a inevitabilidade de existir um princípio ético que organize a vida social: todos têm direito à dignidade. Esta se torna um pressuposto incondicionado para a vida, um valor instituído e, igualmente, reconhecido pelo Estado, pois graças ao respeito ao princípio, funda-se novo tipo de contrato social, que, pelo seu valor, terá consequências práticas no âmbito econômico e político, religioso e social. Não obstante, é preciso que este juízo seja parte integrante da comunidade e tenha na mentalidade da ordem social preponderância sobre outros valores. No fim de contas, a salvação da espécie está na concretude de um tratamento igualitário entre si, mas este só poderá ocorrer se a ordem social tomar medidas efetivas para que esta ideia se torne um valor da comunidade humana.

A dignidade passa, então, a ser a base objetiva da organização estatal, um valor sagrado que não pode ser violado sob risco de coação do infrator. Em outras palavras, não importa os objetivos dos atores, seja no plano individual ou coletivo, no uso de suas liberdades, na busca pela possibilidade de poder, no exercício de sua técnica ou arte. Como os direitos coexistem a todo instante, a qualquer indivíduo será garantida sua devida dignidade. Observa-se, nessa perspectiva, que até os direitos políticos do indivíduo podem lhe ser retirados ou impostos a uma 
reparação ou cárcere privado. Porém, em quaisquer imposições dessas situações deverão ser preservadas as condições que resguardem sua dignidade.

Uma sociedade só assume uma identidade social quando os pressupostos e princípios éticos são compartilhados socialmente por seus membros. 0 princípio de obrigação mútua busca a supressão das desigualdades no sentido geral, mas no stricto sensu, percebem-se vários aspectos: que mudanças estruturais para provocar a excelência do ensino público, por exemplo, podem ser significativas; que os cursos de graduação voltados para área de saúde abandonem as concepções positivas e utilitaristas; que os protocolos de pesquisa adotem como prática geral a substituição dos participantes vulneráveis por sujeitos emancipados; que as pesquisas envolvendo seres humanos fiquem sob o controle social de entidades públicas; e, finalmente, com a consulta aos relatórios enviados aos comitês de ética se possa identificar danos, prejuízos e, igualmente, como são feitas as reparações aos participantes do protocolo. A visualização específica das ocorrências permitirá o levantamento, a nível estatístico, dos bens ${ }^{33}$ jurídicos violados nos protocolos, dando a possibilidade de se edificar uma política de proteção mais efetiva à dignidade da pessoa humana ao mesmo tempo em que permitirá ao legislativo uma tipificação das violações para que, postas na esfera civil e criminal, o judiciário possa aplicar o ordenamento ${ }^{34}$.

Tais proposições não interferem na liberdade do pesquisador, mas ampliam a proteção ao indivíduo ao tempo que promovem contornos inusitados na atividade científica, além de colocar o princípio da dignidade do ser humano como uma medida subjetiva e formal nas relações sociais. Afinal de contas, se a regra se torna senso comum, ela é facilmente assimilada pela moral que, interiorizada na subjetividade do indivíduo, reconhecerá qualquer violação contra a sua dignidade. É imprescindível que essas proposições sejam impostas ao sistema de modo que esses valores sejam reproduzidos nas relações sociais. Em um Estado Democrático de Direito, precisa-se ir além das letras escritas nos documentos, o que só ocorre quando está difundida na mentalidade e na prática dos cidadãos a ideia de direitos e deveres de uns com os outros.

Foi, talvez, por pensar em obrigações correlacionadas e, igualmente, no esquecimento desses compromissos de uns com outros, por parte da comunidade científica, que Van Rensselaer

\footnotetext{
${ }^{33}$ CANTON FILHO, F. Bem jurídico penal. Rio de Janeiro: Elsevier, 2012.

${ }^{34} \mathrm{O}$ juiz precisa "assegurar a verdade real", e, em virtude disso, são obrigados a julgar as condutas por meio das ações observáveis produzidas pelas pessoas em suas vidas social e coletiva. CINTRA, A.; GRINOVER, A; DINAMARCO, C. Teoria geral do processo. São Paulo: Malheiros, 2010. p. 71.
} 
Potter, em "Bioética: ponte para o futuro" 35 , concebeu uma nova sabedoria científica, na qual os valores humanos e conhecimentos biológicos possam ser produzidos com engajamento ético. Ele deixou claro que as ciências devem ter relação com as questões éticas, afinal de contas, elas, e por conseguinte, a busca para aprimorar as boas relações humanas, não devem ser confundidas com a busca pelo aprimoramento técnico-científico ou sua negação: não há relação de causalidade possível entre a tecnoeuforia ou a tecnofobia e o domínio ético.

Albert Schweitzer afirma com propriedade que "o futuro de uma sociedade não reside nas realizações [...] de suas organizações, mas no maior ou menor valor de seus indivíduos” ${ }^{36}$. Com essa perspectiva, Schweitzer aponta que o supremo valor a ser perseguido pela civilização é a vida. Anterior a qualquer discussão se encontra o indivíduo posto no mundo e querendo viver. A ética deve estar a favor dessa circunstância existencial de cada ser no indivíduo e nas estruturas do sistema social. Todavia, não é esse o caso quando se pensa a questão ética como premissa às questões técnico-científicas: estas últimas devem guiar-se conjuntas às proposições de ordem moral como mote para a negação ou aceitação de suas próprias proposições. 0 sucesso das ciências não pode ter a ética como refém.

\section{DO JÁ CONQUISTADO VERSUS O A CONQUISTAR}

A República Federativa do Brasil, formada pela união indissolúvel dos Estados e Municípios e do Distrito Federal, constitui-se em Estado Democrático de Direito e tem como fundamentos: I - a soberania; II - a cidadania; III - a dignidade da pessoa humana; IV - os valores sociais do trabalho e da livre iniciativa; e, por fim, V - o pluralismo político. ${ }^{37}$

O Artigo $1^{\circ}$ da Constituição Brasileira, proclamada em 1988, prevê uma série de consequências pela escolha de edificar a dignidade da pessoa humana como matriz da organização da coexistência social. Decerto que destrinchar entre o teórico e prático destas palavras pode suscitar uma série de feridas. Porém, não há como negar que a Carta Magna expressa claramente os fundamentos da nação brasileira e que, entre a utopia e a realidade pragmática em que vive parte substancial do povo, tem uma longa estrada por atravessar, na qual o cidadão emancipado precisará assumir responsavelmente a defesa dos fundamentos da

\footnotetext{
${ }^{35}$ POTTER, V. R. Bioética: ponte para o futuro. São Paulo: Loyola, 2016.

${ }^{36}$ SCHWEITZER, A. Filosofia da civilização: queda e reconstrução da civilização: civilização e ética. São Paulo: Unesp, 2013. p. 53.

${ }^{37}$ LOUREIRO, L. S. Constituição da República: anotada. São Paulo: Oliveira Mendes, 1998. p. 36.
} 
ordenação estatal, particularmente na eventual defesa de direito violado daquele cidadão que não alcançou a desejada emancipação.

Dentre os fundamentos expostos na Constituição, a dignidade da pessoa humana merece detida atenção. De acordo com o documento, trata-se de valor inerente ao ser, que se expressa em sua consciente autodeterminação e responsabilidade pela própria vida, seja perante o Estado, seja em relação aos outros cidadãos. Este valor se torna universal com as conquistas sociais promovidas mediante a instalação continuada da cidadania. Esse é o marco característico do ser humano e, igualmente, o pressuposto dos direitos que the são próprios, uma vez que garante outro pressuposto: o tratamento igualitário em relação aos seus semelhantes.

Não obstante as palavras que definem e circunscrevem o conceito tornando-o inteligível, a dignidade da pessoa humana precisa ser um valor reconhecido socialmente, referendado e, ao mesmo tempo, compartilhado entre os cidadãos, passando a ser um efeito exterior que cause outras práticas benéficas às pessoas. Afinal de contas, aquilo que afeta a vulnerabilidade de outro cidadão afeta a sua própria, à medida que só se pode ser cidadão sendo cidadão com outros. Por uma perspectiva diferente, a dignidade tem de ser um direito e, igualmente, uma obrigação de uns com os outros, um princípio de responsabilidade que deve ser difundido pedagogicamente entre as ciências, as artes e as profissões. Com efeito, o motivo determinante é o bem supremo, que deve ser garantido pelo ordenamento jurídico, mas, acima deste, quando se torna o conteúdo moral da ação do indivíduo nas suas relações sociais.

Outra mudança significativa ocorreu, no caso do Brasil, nas Diretrizes Curriculares Nacionais dos cursos de graduação vinculados às áreas de saúde e estão se mostrando prepositivos em preparar o estudante para o exercício efetivo da cidadania. Causa ânimo que a Medicina se mostre pioneira no perfil do formando egresso/profissional, ao instituir como meta que, ao final do curso, o estudante deverá ser um:

Médico, com formação generalista, humanista, crítica e reflexiva. Capacitado a atuar, pautado em princípios éticos, no processo de saúde-doença em seus diferentes níveis de atenção, com ações de promoção, prevenção, recuperação e reabilitação à saúde, na perspectiva da integralidade da assistência, com senso de responsabilidade social e compromisso com a cidadania, como promotor da saúde integral do ser humano ${ }^{38}$.

38 DIRETRIZES CURRICULARES NACIONAIS DOS CURSOS DE GRADUAÇÃO EM ENFERMAGEM, MEDICINA E NUTRIÇÃO. Brasília: Diário Oficial da União, 3 out. 2001 . Disponível em: http://portal.mec.gov.br/dmdocuments/ces1133.pdf. Acesso em: 10 jun. 2015. 
Em um país onde a cidadania está em construção, a proposição das diretrizes curriculares nacionais pode ser mais um passo substancial na formação de profissionais que tenham como valor moral consciente a compreensão de outrem, em sua espiritualidade e especificidade como ser humano. Esta orientação representa simbolicamente uma ruptura com as doutrinas positivistas ${ }^{39}$ e pode ser considerada, a médio e longo prazo, como a mais expressiva consequência da influência da bioética que se instalou na discussão acadêmica. No exercício profissional do médico "humanista, crítico e reflexivo" será dada a oportunidade de reconhecer um ser humano que tem direito à devida dignidade mesmo diante de uma sociedade que tem no acúmulo de capital sua orientação precípua.

Em uma sociedade estruturada por silhuetas científicas que atendem às demandas do plano econômico em primeira ordem e, paradoxalmente, aos desígnios que estimularam o capital, uma rede de proteção deve ser garantida ao cidadão vulnerável de modo mais enfático, consoante as medidas sobreditas, permitindo que o violentador de sua dignidade seja interpelado judicialmente por desvios de conduta estabelecidos na legislação, mas também que seu desvio de cuidar de outrem com dignidade tenha repercussões nas relações sociais.

Conforme visto, há diversas formas de tipificar as infrações, delitos e crimes, entretanto, embora seja a dignidade da pessoa humana o paradigma que sustenta a Constituição, é preciso envolver o legislativo para criar o enquadramento regulatório às suas violações a fim de que a morosidade não seja um meio de burlar a devida responsabilidade social do pesquisador. Por tantas vezes, devido à sua formação positivista ${ }^{40}$ e sob a influência das instituições que incentivam a dominação do sistema, o pesquisador pode ser tomado por uma intenção distinta que o leve a conduzir sua atividade sem estar em consonância com suas

\footnotetext{
${ }^{39}$ É evidente que diversas matrizes doutrinárias se sucederam ao longo do tempo desde que o positivismo lançou suas formulações do que era o conhecimento e dos meios "legítimos" de se assenhorar deles. Todavia, não se pode excluir do âmbito da prática científica a ideia difundida de que o saber deve ser buscado como um fim em si mesmo. Tampouco não perceber nas doutrinas utilitaristas uma maneira de garantir este princípio, ainda que recorra às contestadas explicações funcionalistas.

${ }^{40}$ A presença do positivismo e do experimentalismo em solo pátrio pode ser sentida "com maior precisão a receptividade alcançada, no último terço do século XII, pelo novo ideal empirista e positivista de cientificidade estabelecido a partir da noção de medicina experimental, confrontando um discurso do visconde de Sabóia (1835-1909), proferido no ato de doutoramento dos alunos da faculdade de Medicina do Rio de Janeiro, em 1883, com outro, produzido vinte anos antes, em circunstâncias semelhantes, pelo seu antecessor na direção daquela instituição, o conselheiro Jobim (1802-78)". Segundo o comentador, enquanto Jobim discorre "sobre aspectos da profissão médica", o discurso de Sabóia "refletia já a plena confiança nas sólidas bases do saber médico" decorrente das novas influências do positivismo e da medicina experimental. (EDLER, F. C. O debate em torno da medicina experimental no segundo reinado. In: Manguinhos, Vol. III (2), 1996. p. 292-293.)
} 
obrigações mútuas; nestes casos em que expõe o vulnerável, não resta senão a opção de responder em juízo por sua prática abusiva.

A ordenação do sistema se aproveitará de qualquer oportunidade para conseguir lucro, posto que, no fim das contas, o rendimento é a marca característica deste modelo econômico. E esta referência se espraia como valor proeminente das instituições na ordem social a ponto das ações buscarem, seja nos meios, seja no fim, uma forma de obter rendimentos. Estatísticas podem corroborar a afirmação de que a indústria farmacêutica tem os mecanismos necessários para criar mercado de consumo para seus produtos a partir de diagnósticos médicos, o que mostra a influência destas grandes empresas sobre a mentalidade do profissional de saúde.

Há tempos que se difunde a propaganda de que a cura da doença exige uma série de exames e medicamentos a ponto do médico que fugir deste expediente ser considerado pelo leigo como um profissional não qualificado. Ora, as preferências expressam, de modo claro, como as instituições reforçam o comportamento dos indivíduos, mormente, entre os vulneráveis, que devido às desigualdades não tiveram acesso à formação escolar completa e de qualidade. $\mathrm{E}$ os laboratórios conhecendo esta montagem da realidade social, fazem-se presentes na vida do profissional de saúde de maneira que sua influência seja progressiva. Um suave constrangimento pode ser exercido de modo que toda equipe de saúde perceba os bens individuais que podem ser usufruídos se adotarem uma inclinação que venha a beneficiar esta ou aquela indústria. É admissível que o profissional não detecte nenhum conflito de interesse em escolher este ou aquele outro diagnóstico, mas, como as instituições dominam as relações sociais, certamente será possível prever o comportamento de muitos atores sociais e de sua conduta a favor de uma abordagem terapêutica que não trata as doenças a partir das causas que as provocam, mas somente pelos seus efeitos.

Decerto que a dignidade da pessoa humana é, talvez, entendida em sua plenitude pela classe médica. Entretanto, ainda perdura a mentalidade de que o médico não deva abrir um caminho de verdadeira comunicação com seu paciente. Este caminho segue na contramão da linha proposta por Buber ${ }^{41}$, isto é, na ideia de não coisificá-lo. Não obstante, com reservas na afirmação, é um expediente comum perceber, principalmente em hospitais públicos, que as “coisas” encaminhadas ao local são tratadas sem que o profissional da saúde tenha uma real compreensão de que está lidando com um ser humano.

\footnotetext{
${ }^{41}$ BUBER, M. Eu e tu. São Paulo: Centauro, 2001.
} 
O sistema moldou a ideia de que a eficiência exige racionalização dos expedientes e que o exercício profissional deve procurar manter uma distância do paciente para que seus sentimentos não interfiram em seu julgamento clínico. Deste modo, lembrando-se das ideias de Buber, ele se esquece de que o ser humano só se realiza entre humanos, reconhecendo-se na condição igualitária de ser humano. Mas o valor difundido pelas instituições informa que se ele inova em seu expediente e com isso venha a provocar a morte do paciente por não prescrever o modelo dominante, ele escapará à interpelação judicial. Na insegurança do exercício profissional e sob a influência do modelo positivo, o profissional médico se encontra diante de um verdadeiro problema existencial. A ideia de trazer o médico para a discussão se deve à vinculação de que esta categoria foi a mais afetada pela influência positiva e por ser, em grande medida, o pesquisador responsável de muitos protocolos que envolvem o ser humano. 0 médico, assim, escolhe se agarrar aos protocolos de conduta sem se colocar diante do problema da alteridade ${ }^{42}$.

Do que foi exposto acima, e tendo a ideia de que a dignidade é inerente ao ser humano, o profissional deve ter clareza sobre a própria educação ao tempo em que são colocadas à luz as condições objetivas para transformar a proteção à vida como um valor espiritual de sua técnica médica. Por meio da obrigação mútua, ensina-se que o valor de sua existência e a do outro é uma necessidade vital como uma maneira de se alcançar um grau de desenvolvimento e de bemestar, um nível superior de coexistência. É evidente que tal prática existe significativamente por parte daqueles que tomaram consciência de si com respeito ao outro.

Não obstante, a existência social não pode depender exclusivamente desta posição isolada de indivíduos, mas recorrer às condições objetivas de transmissão deste valor para que façam parte do sistema através da reprodução nas relações sociais das instituições da sociedade, e, em especial, por intermédio da educação formal que reflete os valores desejados pela comunidade. As instituições desempenham uma força nuclear indispensável para uma transformação significativa da mudança de mentalidade, pois, em torno delas são construídas as ideias e valores basilares que formam o espírito de uma comunidade.

\footnotetext{
42 "Numa profissão em que a regra é a incerteza, manter esse indivíduo nessas condições, tomado pelo receio onipresente da interpelação judicial dos seus, pelo julgamento de um outro que the é estranho, o tornara subordinado...". Neste ensaio, o profissional de medicina é posto diante de um problema existencial de como exercer a medicina. MACEDO, R. M. Renúncia à arte: ensaio sobre a razão utilitária da medicina contemporânea. São Paulo: Escrituras, 2014.
} 


\section{A ESCOLHA É UM PROBLEMA DE CADA EXISTÊNCIA}

Conquanto os abusos da atividade científica e, igualmente, a emancipação de diversos atores sociais, a bioética trouxe uma discussão sobre os modos de produzir conhecimento que de algum modo ressuscitou a questão filosófica da alteridade de forma mais direta. Numa acepção mais clara, a bioética de modo mais eficiente trouxe a discussão dos valores e da tradição com resquícios positivos e utilitários transvestidos em novas roupagens contemporâneas, promovendo uma reflexão ética na construção das ciências que não se limitaria às clássicas abordagens filosóficas.

Quando se considera a mudança conceitual de "objeto de pesquisa” para "participante de protocolo" não se deve subestimar as consequências morais pela ruptura de vocábulos. Tal mudança se deu em virtude de um debate interpretativo que foi gerado pelas ideias de Potter as quais estão se tornando uma maneira orgânica de percepção da vida. Uma forma de percepção que reconhece que cada existência individual se entrelaça com outras e o meio ambiente. Decorre deste vínculo que uns têm obrigações mútuas com outros.

A constatação de obrigação só pode ser eficazmente colocada na prática com o abandono das velhas influências positivas por outras comprometidas com a dignidade da pessoa humana. Uma mudança significativa está ocorrendo, quer seja na mentalidade trazida pela bioética, quer seja na legislação, através de uma conduta de produção científica com engajamento ético difundida por algumas instituições. Decerto que as relações sociais perceberam que o pressuposto da dignidade não deve ficar restrito aos protocolos de pesquisa, mas na própria forma de se entender o valor da vida humana.

Deste modo, o que parece insignificante com a substituição de palavras, representa um avanço ético que numa visão pública começa a ganhar espaço de que não há mais "objeto de pesquisa" - e, portanto, o ser humano não pode ser coisificado em nome do saber - ao tempo em que a pessoa passa a ser compreendida em sua alteridade como o participante do protocolo que, com sua emancipação, precisa ser convidado de forma autônoma a participar da pesquisa científica. Do objeto da pesquisa que era introduzido, às vezes, à sua revelia, na qual não havia uma possibilidade de defender-se perante um tribunal com sua perspectiva ao cenário atual, percebe-se que a vontade de conhecer todos os domínios da natureza pelas ciências houve uma significativa mudança. Apesar desta conquista, a dignidade simbólica precisa ganhar contornos mais claros para que possa ser "sentida" como um direito natural do ser humano. 
Em outra linha de ação propedêutica, propõe-se um intercâmbio transdisciplinar com as humanidades, incluindo, nos currículos das áreas de saúde, profissionais de filosofia, antropologia e sociologia que possam, efetivamente, promover debates acerca da ética, ao tempo em que intensifica o contato com as questões sociais, patrocinando um processo educacional criativo e responsável com o outro.

Conquanto, em uma sociedade marcada por horizontes científicos, tudo termina sendo absorvido pela política de mercado. Porém, em meio ao mercado, entre seus semelhantes, encontra-se o indivíduo que vive sua existência entre outras. De lado a lado com a existência pessoal, percebe-se que a espécie humana vive entrelaçada à sua, em volta do meio ambiente. $E$ devido a essa correlação, torna-se necessário criar estruturas que definam as regras para coexistir em sociedade. Denomina-se este quadro de "problema da existência", posto que a sua característica mais acentuada seja o conflito que se dá pelo contato e a escolha e, igualmente, a constatação de se estar vivo no meio de outros seres que fazem escolhas que, de algum modo, envolvem nossa vida. $\mathrm{E}$ as regras devem ser decididas, após exaustiva discussão pela maioria, com a cautela de se preservar os direitos inalienáveis do ser humano e o respeito à diversidade de pensamento. Ademais, é indispensável que as deliberações tenham um cuidado prospectivo com a manutenção da vida coletiva no futuro.

Do que foi exposto, merece detida consideração a proposta da bioética que vem ganhando uma aceitabilidade cada vez maior ao mostrar que os seres humanos estão conectados entre si e que uns têm obrigações mútuas com outros.

A bioética de Potter trouxe uma série de discussões sobre as relações de produção do conhecimento e que este deve ser edificado de maneira responsável. A bioética é a resposta moral aos abusos das ciências contra a dignidade da pessoa humana e a não preocupação com o meio ambiente. Todavia, esta proposta não altera as instituições e nem sequer as relações sociais que estão sob sua influência. Trata-se, em última instância, de uma medida existencial, na qual as pessoas responsavelmente vão acordar um dia percebendo que o modo de produção ameaça a própria vida e, assim, procederão a uma mudança de atitude.

Além disso, percebe-se o vínculo da proposta à ideia de que a razão científica servirá como instrumento para promover a consciência de si do cientista. Do ponto de vista institucional, esta razão tomada genericamente reproduz os valores dominantes, por isso que se 
demora décadas para que uma nova concepção ganhe domínio sobre outra ${ }^{43}$. Não se pode deixar de notar que, paradoxalmente, servindo a um propósito, a razão permitiu a tomada de consciência de alguns atores que, emancipados, lutaram para modificar as condições objetivas colocadas pelas classes dominantes. E partindo da ideia de que a razão envolve complexidades e consequências distintas, é indispensável que a razão instrumental que será difundida nas relações sociais e instituições sejam do tipo crítica, plural, sensível e, fundamentalmente, aberta ao diálogo para que seja eficiente para tratar da questão da alteridade. A dignidade, por sua vez, é um direito natural, mas a obrigação mútua de uns com outros precisa ser uma qualidade nuclear que deve buscar a universalidade do direito de que por ser humano já tem direitos inatos.

\section{CONCLUSÃO}

A socialização exige renúncias a certas pulsões que o indivíduo não preparado para a vida coletiva se recusa a abdicar; mas também exige que parte substancial de suas ações, programadas pelas estruturas que moldam a falsa consciência da realidade, sejam modificadas por outras instituições que tenham no pressuposto da dignidade da pessoa humana seu valor supremo. Os valores comuns são socializados como retos, mas somente a reflexão ética pode formular quais são os valores que se deve buscar e quais devem ser renunciados, mesmo quando não há norma escrita que tenha sido colocada como óbice no estatuto jurídico; neste caso, tratar o ser humano com a sua devida dignidade.

A sociedade democrática colocou o princípio da dignidade da pessoa humana como valor estruturante da ordem social e, assim, modificou profundamente a percepção de que a redução da vida ao plano econômico provoca feridas incontornáveis. Do mesmo modo, não se pode esquecer que toda ordenação social está fortemente inclinada para acumulação do capital. Neste ínterim, é preciso desconfiar de qualquer razão que queira colocar a ética a serviço de promover mudanças na geração do conhecimento científico. Diante disso, o princípio de obrigação mútua constitui-se em um pressuposto das pesquisas científicas e exige a tomada da consciência e ações que recaiam sobre o aparelho estatal.

\footnotetext{
${ }^{43} \mathrm{O}$ progresso das ciências não ocorre de modo linear, mas, segundo Kuhn, em meio a crises e revoluções científicas, que ocasionam uma série de situações nas escolhas que levam uma comunidade de profissionais a revisar as bases de sua própria ciência. KUHN, Thomas. A estrutura das revoluções científicas. 5. ed. São Paulo: Perspectiva, 1997.
} 
Orienta-se que os participantes dos protocolos de pesquisas sejam fundamentalmente pessoas emancipadas, principalmente nos anos de formação do pesquisador e em protocolos de alta complexidade que ofereçam grandes riscos às pessoas que participam das pesquisas; que o Estado tenha o controle social dos protocolos de pesquisas, impedindo a existência de comitês de ética independentes; que seja feito um levantamento de danos ocorridos em protocolos com intuito de identificar os mais frequentes para proposição de uma política nacional de proteção à dignidade e, ao final, que em decorrência dos prejuízos ao ser humano, estes danos venham a ser especificamente tutelados em legislação própria. Tais medidas podem ser adotadas imediatamente para dirimir conflitos decorrentes de protocolos de pesquisas. Por fim, e, talvez, não menos significativa, que uma parcela substancial do ensino seja pública, e que a educação oficial do Estado seja na esfera pública ou privada, de concreta qualidade.

Após a consciência de todo o exposto, mais uma vez se percebe que o ser e viver só acontece envolvido e em contato com outrem, pois a vida só acontece entre outras. $E$, segundo Ortega y Gasset, “a vida não elege seu mundo, mas viver é encontrar-se, imediatamente, em um mundo determinado e insubstituível" ${ }^{44}$. Desta exposição nascem os problemas da existência. Por isso que cada um é convidado a escolher o que fará com sua vida diante das circunstâncias concretas em que ela ocorre. E a cada momento é imprescindível escolher entre várias possibilidades que geram, por decorrência, efeitos de suas decisões. Destarte, a questão básica será a da escolha pessoal e, ao mesmo tempo, uma ação sobre as instituições para que haja mudanças significativas nas relações sociais. Sobre esta repousa o ser humano que se é e, ao mesmo tempo, aquele que se deseja ser.

\section{REFERÊNCIAS}

ARISTÓTELES. A Política. Brasília: UnB, 1985.

ARISTÓTELES. Ética a Nicômaco. São Paulo: Atlas, 2009.

BACON, F. Novum Organum ou Verdadeiras indicações acerca da interpretação da natureza. São Paulo: Abril Cultural, 1973.

BEAUCHAMP, T. L.; CHILDRESS, J. F. Princípios de ética biomédica. São Paulo: Loyola, 2002.

${ }^{44}$ ORTEGA Y GASSET, J. Meditações do Quixote. São Paulo: Livro Ibero-Americano, 1967. p. 67. 
BERGER, P. L.; LUCKMANN, T. A construção social da realidade: tratado de sociologia do conhecimento. Petrópolis: Vozes, 1985.

BUBER, M. Eu e tu. São Paulo: Centauro, 2001.

CANTON FILHO, F. Bem jurídico penal. Rio de Janeiro: Elsevier, 2012.

CINTRA, A.; GRINOVER, A; DINAMARCO, C. Teoria geral do processo. São Paulo: Malheiros, 2010.

COMTE, A. Curso de filosofia positiva. São Paulo: Abril Cultural, 1978.

DESCARTES, R. Discurso do método. São Paulo: Martins Fontes, 2001.

DIRETRIZES CURRICULARES NACIONAIS DOS CURSOS DE GRADUAÇÃO EM ENFERMAGEM, MEDICINA E NUTRIÇÃO. Brasília: Diário Oficial da União, 3 out. 2001. Disponível em:

http://portal.mec.gov.br/dmdocuments/ces1133.pdf. Acesso em: 10 jun. 2015.

EDLER, F. C. O debate em torno da medicina experimental no segundo reinado. In: Manguinhos, Vol. III (2), 1996.

FREUD, S. 0 mal-estar na civilização. São Paulo: Abril Cultural, 1978.

FROMM, E. Ter ou ser? Rio de Janeiro: Zahar, 1980.

HUME, D. Tratado da natureza humana. São Paulo: Unesp: Imprensa Oficial, 2001.

HUME, D. Uma investigação sobre o entendimento humano. São Paulo: UNESP, 1999.

KANT, I. Fundamentação da metafísica dos costumes. Lisboa: Edições 70, 2011.

KUHN, Thomas. A estrutura das revoluções científicas. 5. ed. São Paulo: Perspectiva, 1997.

LEÃO, E. C. Aprendendo a pensar. Petrópolis: Vozes, 1991.

LOUREIRO, L. S. Constituição da República: anotada. São Paulo: Oliveira Mendes, 1998.

LÖWY, M. As aventuras de Karl Marx contra o Barão de Münchhausen: marxismo e positivismo na sociologia do conhecimento. São Paulo: Busca Vida, 1987.

MACEDO, R. M. Renúncia à arte: ensaio sobre a razão utilitária da medicina contemporânea. São Paulo: Escrituras, 2014.

MARX, K. O Capital: crítica da economia política. 2. ed. Rio de Janeiro: Civilização Brasileira, 1971.

MÉSZAROS, I. O poder da ideologia. São Paulo: Boitempo, 2004.

ORGANIZAÇÃO DAS NAÇÕES UNIDAS. Declaração dos Direitos do Homem e do Cidadão. 1789. Disponível em: http://www.direitoshumanos.usp.br/index.php/Documentos-anteriores-\%C3\%A0- 
cria\%C3\%A7\%C3\%A3o-da-Sociedade-das-Na\%C3\%A7\%C3\%B5es-at\%C3\%A9-1919/declaracao-dedireitos-do-homem-e-do-cidadao-1789.html. Acesso em: 11 jan. 2016.

ORGANIZAÇÃO DAS NAÇÕES UNIDAS. Declaração Universal de Direitos Humanos. 1948.

Disponível em: http://www.onu.org.br/img/2014/09/DUDH.pdf. Acesso em: 11 jan. 2016.

ORTEGA Y GASSET, J. Meditações do Quixote. São Paulo: Livro Ibero-Americano, 1967.

PLATÃO. A República. São Paulo: Fundação Calouste Gulbenkian, 2001.

POTTER, V. R. Bioética: ponte para o futuro. São Paulo: Loyola, 2016.

POTTER, V. R. Global bioethics: Building on the leopold legacy. Michigan: Michigan State Press, 1988.

ROUSSEAU, J. J. Discurso sobre a origem e os fundamentos da desigualdade entre os homens. Brasília: UnB, 1985.

SCHWEITZER, A. Filosofia da civilização: queda e reconstrução da civilização: civilização e ética. São Paulo: Unesp, 2013.

SMITH, A. Inquérito sobre a natureza e as causas da riqueza das nações. Lisboa: Fundação Calouste Gulbenkian, 1980.

SMITH, A. Teoria dos sentimentos morais. São Paulo: Martins Fontes, 2015.

SOUZA, J. A tolice da inteligência brasileira: ou como o país se deixa manipular pela elite. São Paulo: LeYa, 2015.

TOURAINE, A. Crítica da modernidade. Petrópolis: Vozes, 1997.

WELLS, H. G. A Ilha do Dr. Moreau. Rio de Janeiro: Objetiva, 2012.

ZIMBARDO, P. O Efeito Lúcifer: como pessoas boas se tornam más. Rio de Janeiro: Record, 2007.

ZOLA, E. O romance experimental e o naturalismo no teatro. São Paulo: Perspectiva, 1984.

Recebido em: 27/01/2017 / Revisões requeridas em: 13/06/2017 / Aprovado em: 26/06/2017

\section{COMO CITAR O ARTIGO (ABNT)}

REIS, Nilo Henrique. A PESQUISA CIENTÍfICA NOS DEGRAUS DA BIOÉTICA. Revista Eletrônica do Curso de Direito da UFSM,

Santa Maria, RS, v. 12, n. 2, p. 408-441, ago. 2017. ISSN 1981-3694. Disponível em:

<https://periodicos.ufsm.br/revistadireito/article/view/24336>. Acesso em: dia. mês. ano.

doi:http://dx.doi.org/10.5902/1981369424336. 